\title{
Use of natural isotopes and groundwater quality for improved recharge and flow estimates in dolomitic aquifers
}

\author{
DB Bredenkamp \\ Water Resources Evaluation and Management, Post Net Suite 94, Private Bag X855, Pretoria 0001, South Africa
}

\begin{abstract}
The application of a model to several dolomitic aquifers in the RSA is presented and has successfully simulated the reappearance of ${ }^{14} \mathrm{C}$ injected from nuclear tests in the discharge from springs. This is based on a new conceptual model, which accounts for the large variations of ${ }^{14} \mathrm{C}$ in the groundwater still representing recently recharged water. The input of ${ }^{14} \mathrm{C}$ is related to the recharge mechanism to yield low concentrations if the infiltration is direct; and higher concentrations if the recharge water interacts with biogenic $\mathrm{CO}_{2}$ generated in the soil zone. The model has produced estimates of the recharge parameters and their controls but requires an independent estimate of the average recharge e.g. the chloride mass balance method. A close match has been obtained with ${ }^{14} \mathrm{C}$ measurements over the past three decades. A shallow component of the recharge mixes with a larger and older deep-water component. The model has provided the turn-over times of water in the system, which represent the storage capacity as multiples of the mean annual recharge. Quantitative estimates of the recharge of dolomitic aquifers could be derived from the bicarbonate concentrations of the spring waters.

The model has also been used to simulate the response of the limited temporal tritium measurements and single determinations of CFC for some springs. This has revealed significant differences that are related to additional dilution of the tritium tracer in the unsaturated zone, in comparison to ${ }^{14} \mathrm{C}$ and $\mathrm{CFC}$.
\end{abstract}

Keywords: dolomite, karst, carbonate, aquifers, groundwater, model, carbon $14,{ }^{14} \mathrm{C}$, tritium, ${ }^{3} \mathrm{H}, \mathrm{CFC}$, recharge estimation, turnover time

\section{Introduction}

\section{Background to the study}

In view of their importance as significant groundwater resources the dolomitic aquifers of South Africa have been the focus of studies over many years (Enslin and Kriel, 1967; Fleisher, 1981; Taylor, 1983; Bredenkamp et al., (1985); Foster, 1988; Vegter and Foster, 1990; Simonic, 1993; Bredenkamp et al., 1994; Veltman, 2003; Stephens et al.,2004) A variety of methods have been applied to improve the assessment of the recharge and flow characteristics of these aquifers. The latest contribution involves the simulation of the ${ }^{14} \mathrm{C}$ pulse that had been injected into the atmosphere from thermonuclear tests and its reappearance in the spring discharge after a period of time. The ${ }^{14} \mathrm{C}$ content of several dolomitic springs has been measured at irregular intervals over more than 30 years. Previous attempts (Talma and Weaver, 2003) to simulate the breakthrough of the bomb ${ }^{14} \mathrm{C}$ have only been partially successful in view of:

- The difficulty to determine the initial ${ }^{14} \mathrm{C}$ concentration and account for the large variations in ${ }^{14} \mathrm{C}$ content of the recharge entering the aquifer

- Finding an acceptable mixing model for the water emanating from the spring.

According to the model the recharge comprises two components of different ${ }^{14} \mathrm{C}$ contents that are determined by a low- and a high-threshold rainfall value. Good simulations of ${ }^{14} \mathrm{C}$ have been achieved (Bredenkamp and Van Wyk, 2004).

+27 12 361-6308; e-mail: dbredenkamp@icon.co.za

Received 21 July 2006; accepted in revised form 5 October 2006.
The model has been further investigated to

- Determine the sensitivity of the model parameters

- Match the average recharge obtained from the model to the average recharge derived from the chloride mass balance method (CMB)

- Apply the model to simulate the response of the environmental tritium and CFC in groundwater

- Derive the age and turnover time of water in the aquifer, the latter representing the storage of groundwater as multiples of the average annual recharge. (Vogel, 1970; Bredenkamp and Vogel, 1970).

A WRC contract $(\mathrm{K} 8 / 618)$ has been granted to further investigate the application of the method to dolomitic springs all over the country - see Fig. 1.

\section{Rationale of the ${ }^{14} \mathrm{C}$ model}

The new simulation model conforms to the lumped parameter approach (Maloszewski and Zuber , 1996) but incorporates a bi-modal recharge that could yield both low and high ${ }^{14} \mathrm{C}$ values, which still represent recent recharge (see Fig. 2). A twobox model has provided good results of the mixing occurring within these aquifers, without having to incorporate complex factors such as matrix flow, fracture flow, and dispersion of the tracer.

In the present ${ }^{14} \mathrm{C}$ simulation model the recharge of the dolomite comprises two components according to the conceptual model shown in Fig. 2 with differential uptake of ${ }^{14} \mathrm{C}$. This yields both high and low ${ }^{14} \mathrm{C}$ content for recent recharge, which admixes with water flowing in the aquifer. Recharge in closer proximity to the spring mixes with the deeper flowing water, representing recharge that has occurred at greater distances from the spring outlet, which represents recharge from an earlier period. The ${ }^{14} \mathrm{C}$ content of the final mix therefore 
depends on the proportion of shallow water that mixes with a larger component of deeper water. However, the relative contributions of the shallow and deep components will always remain the same, as the recharge determines the groundwater levels and hydraulic head, which controls the fluctuating discharge of the springs.

\section{Reliable recharge as reference}

From a selection of available methods the chloride mass balance method representing the ratio of the rainfall chloride to that of the groundwater (CMB method - Beekman and $\mathrm{Xu}, 2003$ ), is the best method to use, provided that no chloride is contributed by the geological formations or contamination. Refined measurement of the chloride in the rainfall has been initiated but needs to be continued over a longer period. The average recharge could be derived from the spring flows if the recharge area of the springs can be delineated reliably, and the chloride content of the rainfall could be inferred from the best match between the simulated chloride concentrations and the measured chloride of the spring water. These results have indicated that the relationship between chloride and rainfall (Bredenkamp et al., 1995), which has been based on reported measurements at the time, has overestimated the chloride concentration of the rainfall by about $40 \%$, resulting in the same overestimation of the average recharge.

\section{${ }^{14} \mathrm{C}$ simulation model (compiled in Excel)}

\section{Conceptual model}

BIMODAL RECHARGE IN DOLOMITIC AQUIFERS

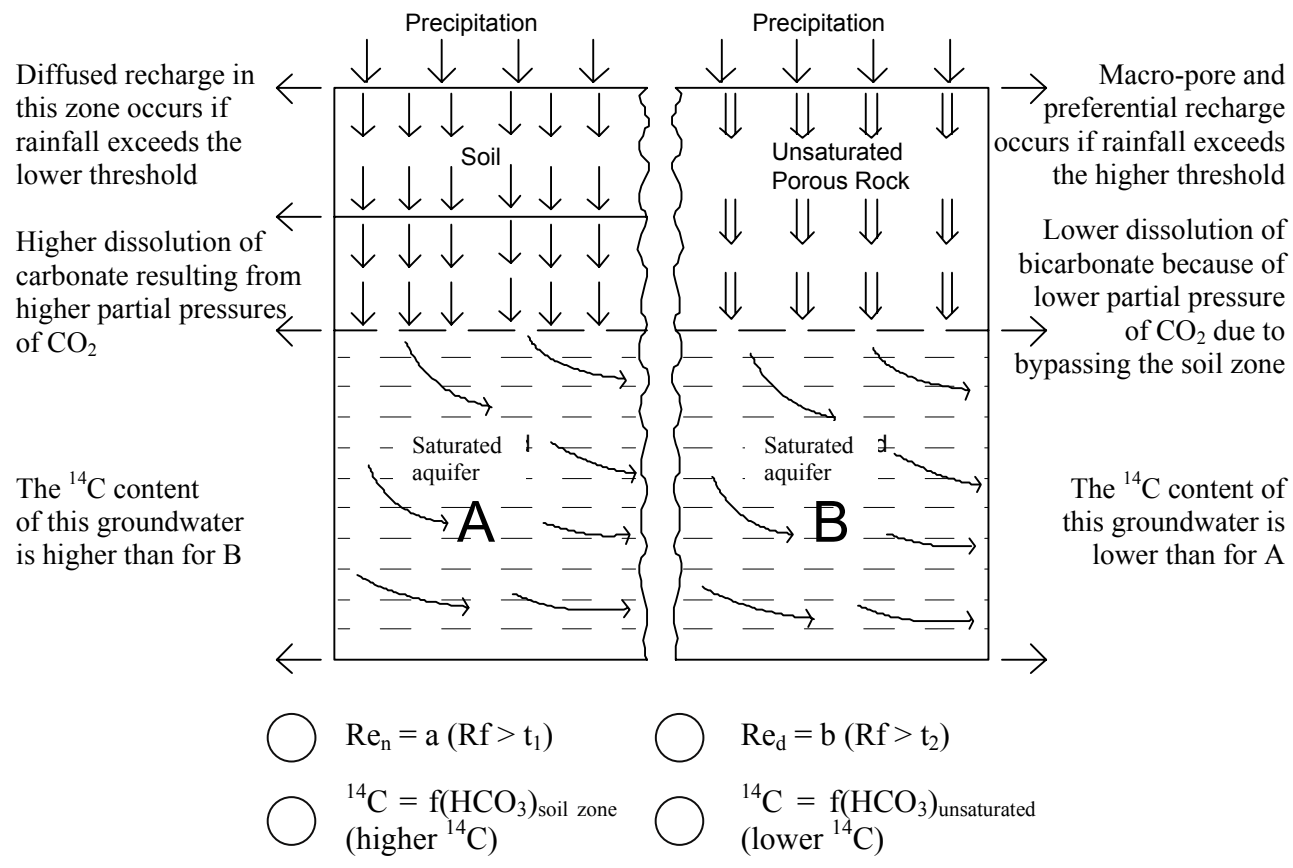

Figure 2

Schematic diagram of the bimodal ${ }^{14} \mathrm{C}$ input of the model that controls the input of ${ }^{14} \mathrm{C}$ derived from normal $\left(R e_{n}\right)$ and direct $\left(R e_{d}\right)$ recharge where $t_{1}$ and $t_{2}$ are the threshold rainfalls and $a$ and $b$ the recharge coefficients for the normal and direct recharge (see Eq.(1)
The rationale of the postulated bi-modal recharge is schematically presented in Fig. 2 and the recharge components of the model are set out below and have been adjusted so that the average recharge corresponds to independent estimates of the average recharge, e.g. from the CMB method:

- In addition to the 'normal' recharge (e.g. diffused flow through the soil zone), a recharge factor that operates during periods of high rainfall is introduced. The latter represents the more direct macropore recharge. This produces a gradual exponential increase in the recharge for increased precipitation. 
- A cut-off value to the monthly rainfall is applied to the 'normal' recharge component, while a significantly higher threshold applies to the high rainfall component. No water is contributed by the recharge component below these thresholds.

- Of the monthly excess rainfall only a fraction reaches the groundwater table - the rest is predominantly lost by evapotranspiration and runoff is negligible from these aquifers

- A further weighting factor is applied to the fractions. It increases/decreases as the average precipitation of preceding months is higher/lower than the long-term average and further contributes to the exponential response of recharge.

- The relative amount of recharge in a specific month is furthermore determined by the average of the excess rainfall values over a number of foregoing months.

The relative recharge of month i from the two components is thus given by:

$$
R_{i}=\left(\frac{a w}{u} \sum_{i-u+1}^{i}\left(R f_{i}>t_{1}\right)+\frac{b w}{v} \sum_{i-v+1}^{i}\left(R f_{i}>t_{2}\right)\right)
$$

where:

$\left(R f_{i}>t_{1}\right)$ and $\left(R f_{i}>t_{2}\right)$ are the precipitation values for month i greater than $t_{1}$ and $t_{2}$, respectively

$a$ and $b$ are the respective fractions of the rainfall that reaches the saturated zone

$w=\frac{1}{x R f_{\text {ave }}} \sum_{i=x+1}^{i} R f_{i}$ is the weighting factor

$\mathrm{Rf}_{\text {ave }}$ is the long-term rainfall average

$\mathrm{u}$ and $\mathrm{v}$ and $\mathrm{x}$ are the number of months over which the summation is carried out. In this application they could vary between 12 and 48 months.

The model to simulate the ${ }^{14} \mathrm{C}$ in the spring discharge has the following features:

- The relative ${ }^{14} \mathrm{C}$ content of the two components of the recharge is calculated in a similar manner as for the actual amounts of the recharge. Thus the monthly value of the atmospheric ${ }^{14} \mathrm{C}$ times the excess rainfall amount is averaged over several previous months and multiplied by the fraction relating to the dilution of the ${ }^{14} \mathrm{C}$ during the dissolution of carbonate. The two components thus obtained are added and the sum is divided by the total recharge to give the ${ }^{14} \mathrm{C}$ content of the water reaching the water table for each month.

- The admixture of water in the aquifer is treated by two wellmixed boxes: a shallow box that contains the recent recharge and more rapidly reaching the spring outflow, and a deeper one that represents the average recharge over a preceding period of several decades.

- At the spring several multiples of the deep box mix with the water from the shallow box to determine the ${ }^{14} \mathrm{C}$ of the discharge

- Finally, a lag-time of up to a few years is introduced to the outcome of the simulated ${ }^{14} \mathrm{C}$ values. It mainly represents the time lag that is effected in the unsaturated zone, which has not been incorporated in the mixing model, as well as a possible delay in the transmission of the tracer through the aquifer; however, no provision has been made for dispersion.

The ${ }^{14} \mathrm{C}$ content of the water derived from the two-box model in month $\mathrm{i}$ is given by Eq. (2) below:

$$
C_{i}=\frac{1}{p+1}\left(\left[\frac{g a w}{u} \sum_{i-u+1}^{i} A_{i}\left(R f_{i}>t_{1}\right)+\frac{h b w}{v} \sum_{i-v+1}^{i} A_{i}\left(R f_{i}>t_{2}\right)\right] \frac{1}{R_{i}}+\frac{p}{j-k} \sum_{i-k+1}^{i-1} C_{i}\right)
$$

\section{$\mathrm{A}_{\mathrm{i}}$ is the ${ }^{14} \mathrm{C}$ value of atmospheric $\mathrm{CO}_{2}$ in month $\mathrm{i}$}

$\mathrm{g}$ and $\mathrm{h}$ are the fractions of $\mathrm{A}_{\mathrm{i}}$ in the two components of the recharge determined from the model and the bicarbonate concentrations

$\mathrm{p}$ is the multiple of deep water that mixes with the shallow water fraction from the spring

(j-k) is the summation period, i.e. the number of months prior to $\mathrm{j}$ over which the deep water is averaged (usually several hundred months) and is summed up to month i-1 (i.e. values of $C$ that are already calculated)

$\mathrm{j}$ is mostly 36 because of it being the rainfall period that on average corresponds best to the flow of the springs

The parameter $\mathrm{p}$ indicates that the deep flow component probably extends over a longer period than $\mathrm{j}-\mathrm{k}$, which is the reason why multiples of the deep flows have to be incorporated in view of limited historical ${ }^{14} \mathrm{C}$ input from too short a rainfall record.

The best simulation is obtained by interactive adjustment of the parameter values until the smallest least-square fit between the observed and simulated values has been obtained. At the same time, the simulated average recharge and average bicarbonate should correspond to the measured values.

\section{Application of the model}

\section{Deriving the characteristics of dolomitic aquifer systems}

The ${ }^{14} \mathrm{C}$ model has been applied to most of the monitored springs in the different areas and the best simulations of a selection of major springs are shown in Fig. 3 (next page), also indicating the ${ }^{14} \mathrm{C}$ input content in the atmosphere. The parameters that have been derived for this group are listed in Table 1.

\section{Deriving the turnover time and age of water in the aquifer}

The turnover time $\mathrm{T}$ of water discharging from the different springs and the average age of the water emerging from the springs are derived according to Eqs. (3) and (4). The turnover time represents the ratio of the total groundwater in storage to the average annual recharge (Bredenkamp and Vogel, 1970), and it provides an indication of the time it would take for a contamination pulse to be flushed from these aquifers.

$$
T=\frac{n_{1}+n_{2} * p}{(p+1) * 12}
$$

where:

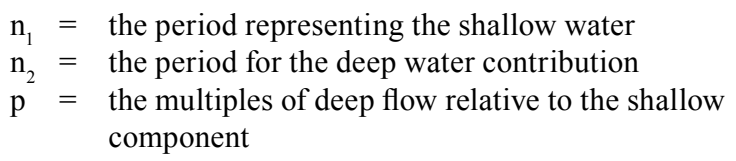

which yields:

total age of water $(\mathrm{yr})=$ turnover time $(\mathrm{yr})+$ final lag $\mathrm{L}$ (months)/12 

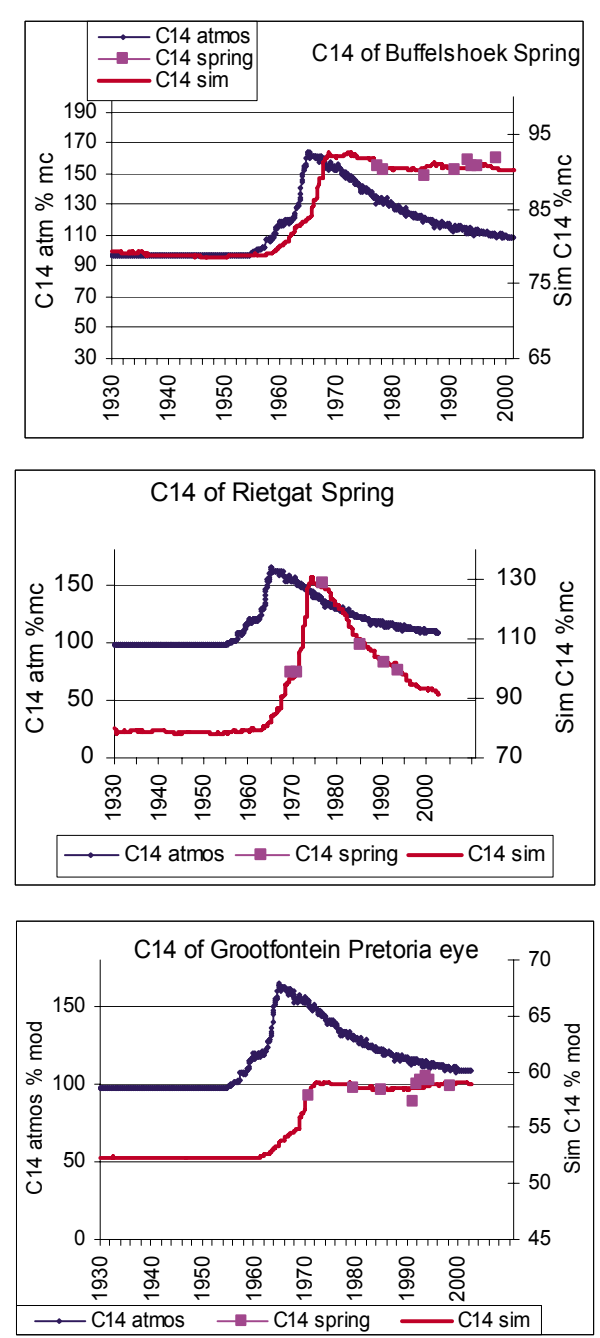
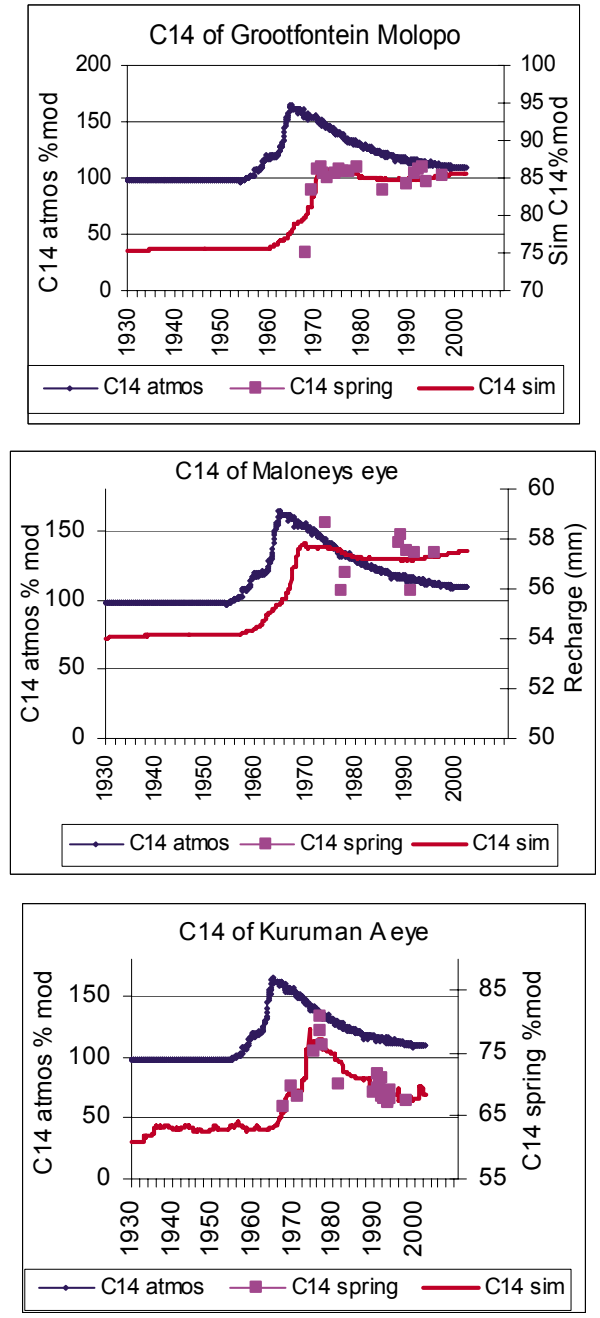

Figure 3

Graphs of the ${ }^{14} \mathrm{C}$ observations in comparison to the simulated values for a selection of dolomitic springs in different areas
The final lag L (Table 1) in fact means that the measured ${ }^{14} \mathrm{C}$ content of a specific month has been the response to rainfall effectively starting $\mathrm{L}$ months earlier than month $\mathrm{i}$.

The model has provided reliable estimates of the average recharge that corresponded to the values derived from the CMB method and conforming to the time-varying response of the spring discharge. The same applies to the average simulated and measured bicarbonate content of the spring.

Table 1 shows good comparison of parameters for the various aquifers derived from the ${ }^{14} \mathrm{C}$ modelling, e.g.:

- The high threshold rainfalls are very similar and variations of the lower threshold can be related to the thickness and extent of the superficial cover overlying the aquifer. In the case of Rietgat Spring and Kuruman A Spring the surfaces are largely covered by calcrete, which seems to be linked to a large final lag that has to be further investigated.

- For most of the aquifers, the normal recharge coefficient is the dominant component.

- The ${ }^{14} \mathrm{C}$ coefficient of the normal recharge component is always higher than that of the direct recharge.

- The multiples of deep flow (p) that have yielded the best simulation for the smaller compartments and larger for the big compartments, with Buffelshoek Spring being an exception, apparently because of overflow occurring from compartments higher up. For Rietgat the value of $p=0$ indicates that there is no deep flow component but its long lag still needs further clarification.
- The final lag shows a large variation ranging from a few months to 86 months for Rietgat and 133 months in the case of Kuruman. The monthly variability of the recharge of springs with flow records corresponds well with the value simulated from the ${ }^{14} \mathrm{C}$ model.

The successful simulation of the ${ }^{14} \mathrm{C}$ of springs in dolomitic aquifers of the Northwest, Gauteng, Far West Rand and Kuruman regions indicates that the parameters conform to the conceptual bi-modal recharge and mixing model. The results reveal that the smaller the contribution of the deep flow, the more the outflow ${ }^{14} \mathrm{C}$ pulse conforms to the shape of the input tracer pulse. The larger a compartment is, the higher the deep flow component generally is, whilst a greater final lag apparently applies when the unsaturated zone comprises calcrete deposits. Typical examples are those of the Rietgat Spring, Molopo Eye and Kuruman A Spring as is indicated in Table 1. The controlling parameters of the recharge, e.g. the threshold rainfalls and coefficients of recharge of the two components showed a great deal of similarity. The low threshold rainfall is in the range of $20 \mathrm{~mm}$ and the high threshold is about $60 \mathrm{~mm}$ per month for direct recharge to occur.

The low concentrations of ${ }^{14} \mathrm{C}$ of Maloneys Eye and Pretoria Grootfontein Springs initially appeared non-typical of dolomitic springs. However, a reassessment of the Grootfontein Spring (Pretoria) has revealed that the recharge coefficient is about $16 \%$ and is entirely derived from the dolomite and not from the adjacent quartzite aquifer. 
TABLE 1

A summary of results of the ${ }^{14} \mathrm{C}$ simulations of selected springs from the different dolomitic areas

\begin{tabular}{|c|c|c|c|c|c|c|c|}
\hline SPRINGS & $\begin{array}{c}\text { Buffels- } \\
\text { hoek }\end{array}$ & $\begin{array}{c}\text { Grootftn } \\
\text { Mol }\end{array}$ & Rietgat & $\begin{array}{c}\text { Grootftn } \\
\text { Pretoria }\end{array}$ & Maloneys & \begin{tabular}{|c|} 
Gerrit \\
Minnebron
\end{tabular} & $\underset{\text { Kuruman }}{\text { Ka }}$ \\
\hline Low threshold $\left(\mathrm{t}_{1}\right)$ & 12.5 & 29.7 & 26.8 & 23.5 & 15.5 & 10 & 20 \\
\hline High threshold $\left(\mathrm{t}_{2}\right)$ & 63.9 & 38.2 & 51.4 & 61.4 & 55.9 & 74.5 & 65 \\
\hline Normal recharge factor (a) & 0.112 & 0.084 & 0.065 & 0.15 & 0.109 & 0.09 & 0.106 \\
\hline Direct recharge factor (b) & 0.065 & 0.114 & 0.034 & 0.084 & 0.056 & 0.06 & 0.07 \\
\hline${ }^{14} \mathrm{C}$ factor $(\mathrm{N})(\mathrm{g})$ & 0.83 & 0.853 & 0.881 & 0.545 & 0.57 & 0.75 & 0.658 \\
\hline${ }^{14} \mathrm{C}$ factor $(\mathrm{D})(\mathrm{h})$ & 0.592 & 0.551 & 0.682 & 0.504 & 0.558 & 0.50 & 0.551 \\
\hline Deep flow mix factor $(p)$ & 3.19 & 4.12 & 0 & 4.29 & 9.55 & 8.83 & 2.31 \\
\hline Mix period $1(\mathrm{n} 1)$ & 36 & 36 & 36 & 36 & 36 & 36 & 240 \\
\hline Mix period $2(\mathrm{n} 2)$ & 348 & 338 & No deep & 329 & 460 & 548 & 597 \\
\hline Turnover time (years) & 11.6 & 12.8 & 1.5 & 12.7 & 16.1 & 22 & 22.4 \\
\hline Rf weighting w (months) & 24 & 24 & 24 & 36 & 36 & 36 & 60 \\
\hline Aver. period (>N-thresh) (mths) & 12 & 36 & 36 & 36 & 36 & 36 & 36 \\
\hline Aver. period (>H-thresh)(mths) & 12 & 36 & 36 & 24 & 36 & 36 & 36 \\
\hline Final lag L Sim ${ }^{14} \mathrm{C}$ (months) & 74 & 57 & 86 & 61 & 29 & 16 & 133 \\
\hline Sim $\mathrm{HCO}_{3}$ of spring $(\mathrm{mg} / \ell)$ & 228.6 & 222.1 & 238.8 & 79.8 & 97.0 & 181 & 149 \\
\hline Measured $\mathrm{HCO}_{3}(\mathrm{mg} / \ell)$ & 228.8 & 228 & $285^{*}$ & 117 & 130 & $201 *$ & 162 \\
\hline Recharge area $\left(\mathrm{km}^{2}\right)$ & 32 & 92 & 38 & 28.7 & 234 & 796 & 286 \\
\hline $\mathrm{Cl}$ of spring $(\mathrm{mg} / \ell)$ & 7.4 & 6.4 & & 4.8 & 3.3 & 7.5 & 5.3 \\
\hline Recharge $\%$ of average Rf & 7.5 & 8.9 & 7 & 13 & 12 & 8.4 & 8.5 \\
\hline${ }^{14} \mathrm{C}$ Recharge $\%$ of av. $\mathrm{Rf}$ & 7.5 & 8.9 & 9.6 & 13 & 12 & 8 & 8 \\
\hline
\end{tabular}

* Slight pollution of aquifer

\section{Comparison of the ${ }^{14} \mathrm{C}$ simulations with tritium and CFC measurements}

Concurrently with the ${ }^{14} \mathrm{C}$ input from thermonuclear tests, a similar tritium pulse has been released into the atmosphere, although its maximum concentrations have been 30 times that of the pre-bomb levels compared with 1.6 times in the case of ${ }^{14} \mathrm{C}$. The pre-bomb tritium levels have increased from about $2 \mathrm{TU}$ (tritium units) to about $60 \mathrm{TU}$ in 1962 and have thus provided a distinct signal to the groundwater recharge to trace its propagation through the aquifer. However, in view of the radioactive decay of tritium (half-life of 12.3 years), the tritium input into the aquifer had to be corrected for each of the simulated months with incorporation of the final lag as well.

Measurements of tritium have been carried out only for some of the springs and were modelled according to the same set of parameters that have been derived from the best ${ }^{14} \mathrm{C}$ simu- lations, except that there is no differentiation in the bi-modal input. Some of the results for tritium are shown in Figs. 4a and $4 \mathrm{~b}$. Table 2 indicates that larger contributions of deep flow have to be incorporated to obtain a good fit in the case of tritium than for the ${ }^{14} \mathrm{C}$ simulation, while for $\mathrm{CFC}$ they were smaller than for ${ }^{14} \mathrm{C}$.

The higher contribution of deep flow in the case of tritium is probably caused by the fact that additional dilution of the input of tritium occurs in the unsaturated zone overlying the aquifer. This is not the case with the ${ }^{14} \mathrm{C}$ input, which is effected at the depth of the root zone. In the model, the mixing only occurs as though the recharge of a specific month enters the saturated zone without any dilution. A larger multiple of deep flow is therefore required in the case of tritium to best simulate the measured levels. Hence, the larger deep-flow component for the tritium simulation than that of the ${ }^{14} \mathrm{C}$ simulation is an indication of the impact of the unsaturated zone.
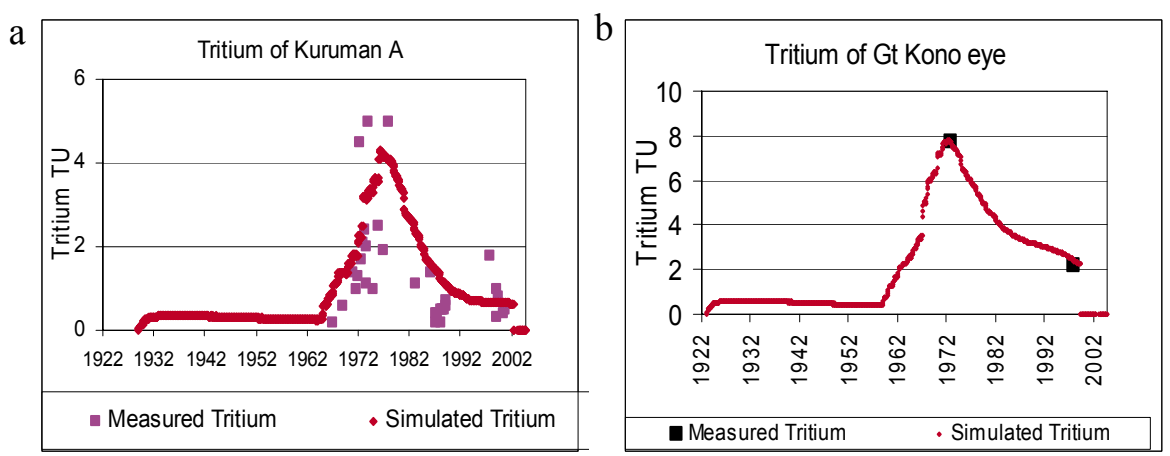

Figure $4 a$ and $b$

Typical simulations of the tritium content of springs based on the parameter values for the best ${ }^{14} \mathrm{C}$ model, which in this case required a higher contribution of deep flow than for ${ }^{14} \mathrm{C}$ (see Table 2). 

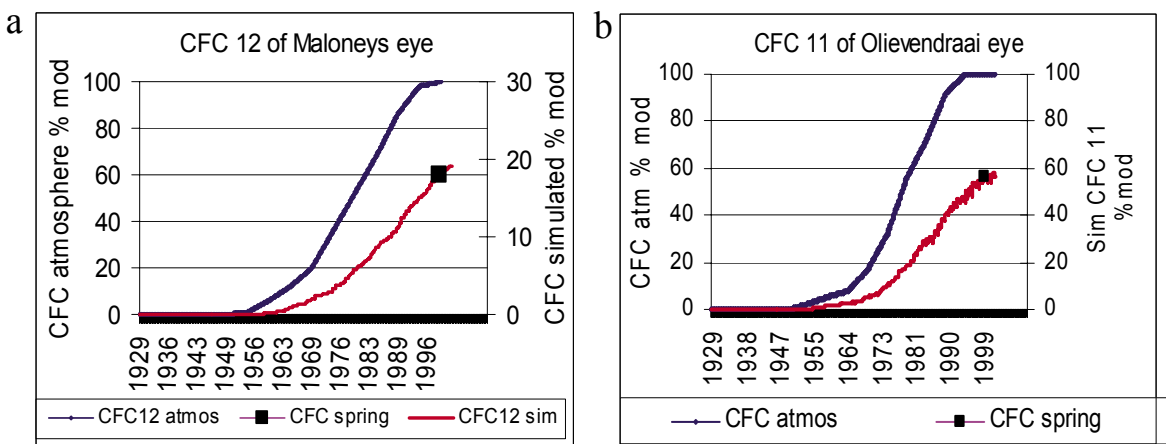

Figure 5a and $b$

Simulations of CFC concentrations of two springs using the parameter values that have produced the best fit for the ${ }^{14} \mathrm{C}$ model (see Table 2)

It appears that in the case of CFC a smaller contribution of deep flow is required than for the ${ }^{14} \mathrm{C}$ simulations, which conforms, as is generally assumed, to the input of CFC occurring at the interface between air and the saturated water level of the aquifer. Therefore, it would seem that the different responses of the tracers could be explained by their input mechanisms. The ${ }^{14} \mathrm{C}$ simulations are more reliable in view of fewer analysis of tritium and only single CFC measurements have been carried out.

\section{Assessment of the pollution of an aquifer based on the ${ }^{14} \mathrm{C}$ model}

\section{Simulation of the transmission of pollution through a dolomitic aquifer}

Springs in the West Rand dolomitic aquifers (Fig. 1) have been polluted by the gold mines, e.g. Turffontein and Gerrit Minnebron. In cases of accidental spillage a reliable evaluation of the environmental impact and the effectiveness of clean-up measures is often required. The parameters obtained from the ${ }^{14} \mathrm{C}$ model and the mixing models have been used to derive the pollution input and its temporal variation for different recharge scenarios (see Fig. 6). From inverse modelling it appears that the pollution had commenced at about 1959 and had remained constant up to about 1977, whence it had increased and remained effectively constant from 1988 until 2001 (Fig. 6). The decontamination response can be simulated assuming that the influx of the pollution stopped in 2001 and is being flushed out, by extending the rainfall sequence by the series experienced over the past 60 years. This indicates that the pollution pulse would only be reduced to $100 \mathrm{mg} / \ell$ after 64 years.

\section{Bicarbonate concentrations}

The bicarbonate of the bi-modal recharge components of the ${ }^{14} \mathrm{C}$ model is based on a linear interpolation between the two extremes in the bicarbonate dissolution-equilibrium shown in Fig. 7. A maximum concentration of $280 \mathrm{mg} / \ell$ of bicarbonate is attained during slow movement of recharge through the unsaturated zone where biogenic $\mathrm{CO}_{2}$ is released by the plant roots. This corresponds to a ${ }^{14} \mathrm{C}$ factor of 0.9 used in the model. A minimum concentration of $51 \mathrm{mg} /$ / represents a ${ }^{14} \mathrm{C}$ factor of 0.5 that applies if recharge occurs directly to the saturated zone to dissolve carbonate having by-passed the root zone of the vegetation. Depending on the relative proportions of direct and normal recharge, the bicarbonate concentrations of the water emanating from a spring will vary between these extreme values.

\begin{tabular}{|c|c|c|}
\hline \multicolumn{3}{|c|}{$\begin{array}{c}\text { TABLE } 2 \\
\text { A comparison between the multiples of deep flow } \\
\text { for }{ }^{14} \mathrm{C} \text { tritium and CFC for typical springs that have } \\
\text { been monitored }\end{array}$} \\
\hline \multirow{2}{*}{\begin{tabular}{|l|} 
Spring \\
Buffelshoek Eye
\end{tabular}} & \multicolumn{2}{|c|}{ Multiple of deep flow } \\
\hline & ${ }^{14} \mathrm{C}$ & 3.18 \\
\hline \multirow[t]{2}{*}{ Doornplaat } & ${ }^{14} \mathrm{C}$ & 3.96 \\
\hline & $\mathrm{CFC}$ & 1.67 \\
\hline \multirow[t]{2}{*}{ Gerrit Minnebron* } & ${ }^{14} \mathrm{C}$ & 15.2 \\
\hline & $\mathrm{CFC}$ & contam \\
\hline \multirow[t]{3}{*}{ Gftn Mol } & ${ }^{14} \mathrm{C}$ & 4.12 \\
\hline & Tritium & 6 \\
\hline & $\mathrm{CFC}^{*}$ & 0.33 \\
\hline \multirow[t]{2}{*}{ Kuruman A Eye } & ${ }^{14} \mathrm{C}$ & 2.68 \\
\hline & Tritium & 12 \\
\hline \multirow[t]{2}{*}{ Kuruman B } & ${ }^{14} \mathrm{C}$ & 4.94 \\
\hline & Tritium & 11 \\
\hline \multirow[t]{2}{*}{ Manyeding } & ${ }^{14} \mathrm{C}$ & 0.82 \\
\hline & Tritium & 7 \\
\hline \multirow[t]{2}{*}{ Molopo Eye } & ${ }^{14} \mathrm{C}$ & 7.62 \\
\hline & Tritium & 11.5 \\
\hline \multirow[t]{2}{*}{ Olievendraai } & ${ }^{14} \mathrm{C}$ & 1.08 \\
\hline & $\mathrm{CFC}$ & 1.0 \\
\hline Paardevlei & ${ }^{14} \mathrm{C}$ & 2.03 \\
\hline Pta Erasmus fount & ${ }^{14} \mathrm{C}$ & 17.18 \\
\hline Pta Grootfontein & ${ }^{14} \mathrm{C}$ & 11.98 \\
\hline \multirow[t]{2}{*}{ Renosterfontein } & ${ }^{14} \mathrm{C}$ & 2.59 \\
\hline & $\mathrm{CFC}$ & 0.95 \\
\hline \multirow[t]{2}{*}{ Schoonspruit Eye } & ${ }^{14} \mathrm{C}$ & 1.5 \\
\hline & Tritium & 10.5 \\
\hline Turffontein & ${ }^{14} \mathrm{C}$ & 2.01 \\
\hline \multirow[t]{2}{*}{ Upper Mooirivier } & ${ }^{14} \mathrm{C}$ & 10.86 \\
\hline & CFC & 3.45 \\
\hline Vergenoegd Eye & ${ }^{14} \mathrm{C}$ & 2.53 \\
\hline \multirow[t]{2}{*}{ Groot Kono Eye } & ${ }^{14} \mathrm{C}$ & 1.5 \\
\hline & Tritium & 6.5 \\
\hline \multirow[t]{2}{*}{ Klein Kono Eye } & ${ }^{14} \mathrm{C}$ & 1.9 \\
\hline & Tritium & 4.71 \\
\hline Pta Fount Upper & ${ }^{14} \mathrm{C}$ & 2.62 \\
\hline Pta Sterkfontein & ${ }^{14} \mathrm{C}$ & 2.23 \\
\hline \multirow[t]{2}{*}{ Maloneys } & ${ }^{14} \mathrm{C}$ & 9.55 \\
\hline & $\mathrm{CFC}$ & 5.95 \\
\hline
\end{tabular}

*Sample contaminated 


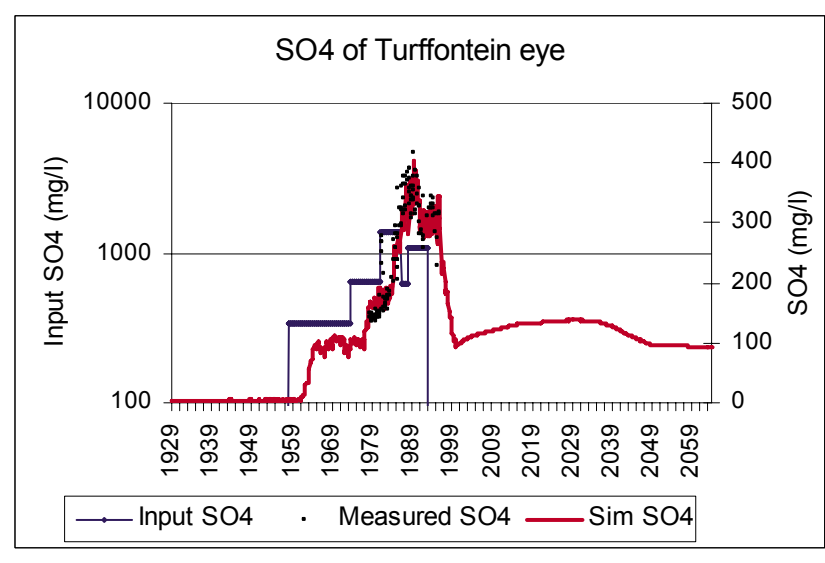

Figure 6

The simulated pollution of Turffontein Spring vs. the measured concentrations

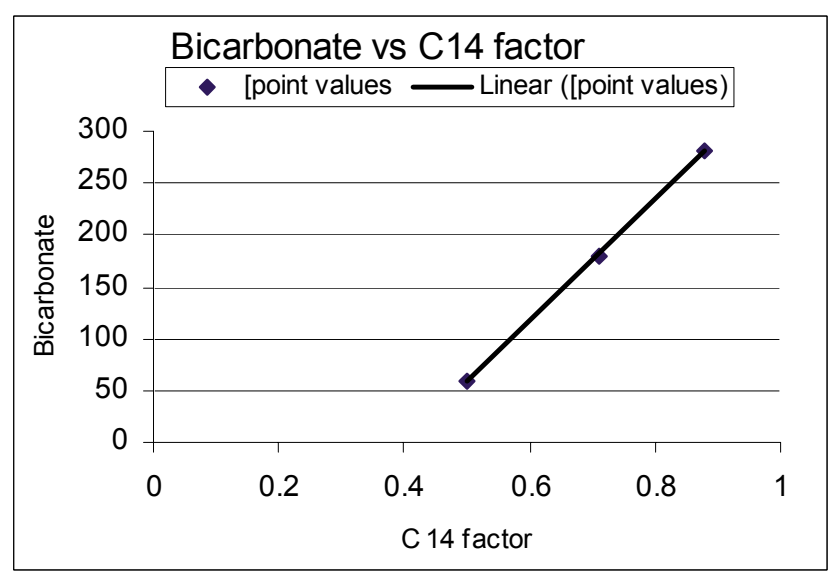

Figure 7

Relationship between the bicarbonate concentrations and the ${ }^{14} \mathrm{C}$ factor used in the simulation model to derive the bicarbonate concentrations

The bicarbonate content of the spring water that has been derived from the relationship shown in Fig. 7 with revised chloride values of Pretoria dolomite, has shown an inverse linear relationship if plotted against reliable estimates of recharge (see Fig. 8). The recharge derived from the chloride mass-balance ratio has been used as the reference recharge values. The bicarbonate concentrations of the spring waters could thus be used to obtain a provisional independent estimate of the average recharge of dolomitic aquifers for all dolomitic aquifers of South Africa. Similarly, the bicarbonate of individual boreholes would reflect the spatial variability of recharge experienced over the recharge area of the various springs.

\section{Simplified rainfall-recharge relationship}

An important outcome of the ${ }^{14} \mathrm{C}$ model is that the monthly recharge values reduce to an exponential relationship in relation to the average rainfall over a characteristic period ignoring the threshold rainfall values and weighting factors that have been used in the ${ }^{14} \mathrm{C}$ model.

The exponential relationships shown in Figs. 9 and 10 are similar to the one derived by Van Rensburg (2004) to simulate the monthly recharge from rainfall, but which still incorporates a cut-off threshold rainfall. The newly derived relation-

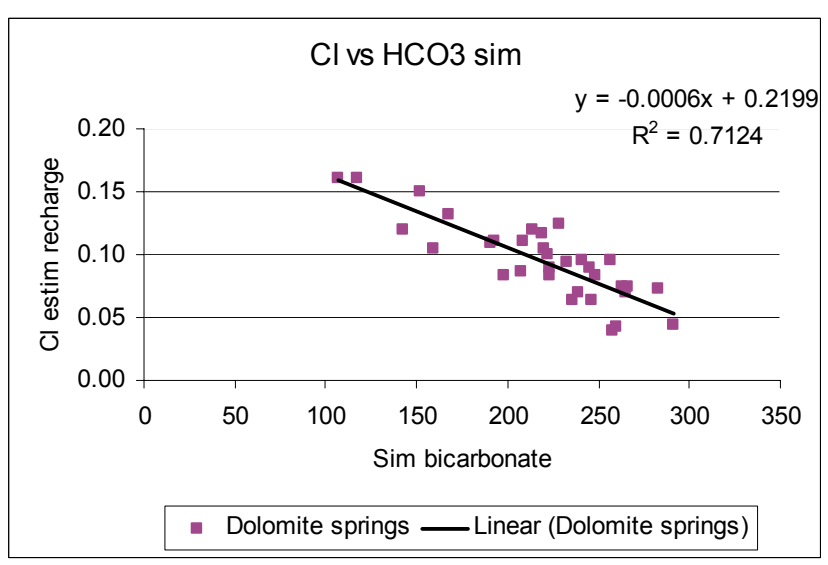

Figure 8

Relationship between the bicarbonate concentrations of the different dolomitic springs and the average recharge coefficients derived from the chloride method

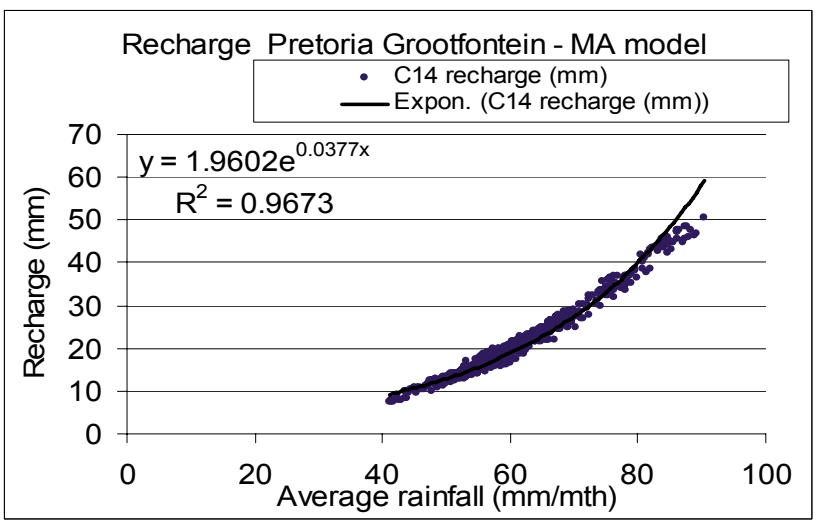

Figure 9

Exponential relationship between the monthly recharge derived from the ${ }^{14} \mathrm{C}$ simulation model and the average rainfall over the preceding 36 months without the incorporation of the threshold rainfalls

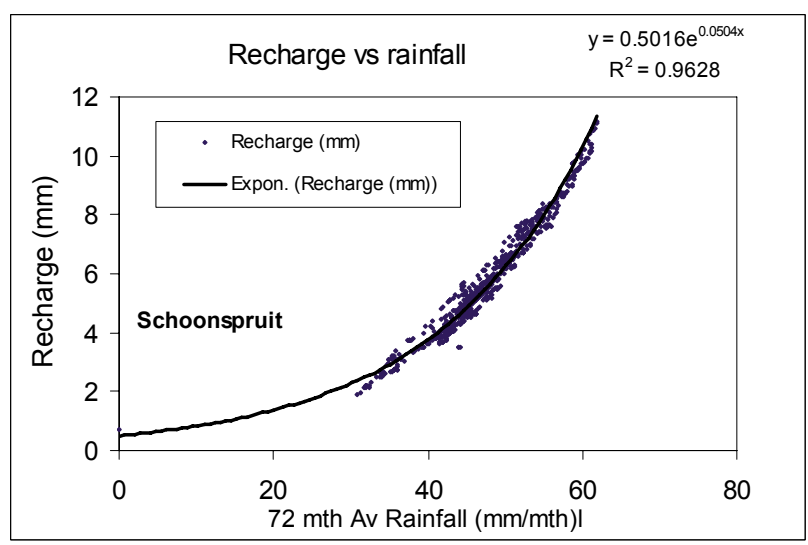

Figure 10

The monthly natural flows of Schoonspruit eye $(\mathrm{mm} /$ month) in relation to the average rainfall over 72 months for a recharge area of $842 \mathrm{~km}^{2}$ as derived by Veltman (2003), without the incorporation of threshold rainfalls

ship provides a method to simulate the temporal response of the groundwater levels from which the reserve and the allocations of groundwater in the periods of surplus could be derived. 
It is evident that the ${ }^{14} \mathrm{C}$ model could be simplified by deriving the monthly recharge using the new exponential relationship to determine the ${ }^{14} \mathrm{C}$ input. Likewise the bi-modal recharge components could be substituted by a single recharge coefficient with a corresponding initial ${ }^{14} \mathrm{C}$ coefficient that is determined by the bicarbonate relationship shown in Fig. 7.

\section{Conclusions}

The successful simulation of the reappearance of the bomb ${ }^{14} \mathrm{C}$ in dolomitic springs, based on the new tracer model programmed in Excel, has:

- Provided evidence in support of the bi-modal recharge model controlling the input of ${ }^{14} \mathrm{C}$, although it appears that reasonably good simulations could also be obtained by using a simpler model

- Clearly indicated that a two-box model, mixing recharge from a recent period with water from a longer preceding period, is an essential component of the model

- Confirmed that reliable estimation of groundwater recharge is critical to obtain reliable estimates of the aquifer parameters

- Provided successful simulations of the ${ }^{14} \mathrm{C}$ of several springs in spite of the availability of only intermittent measurements over a period of more than 30 years

- Enabled derivation of the turnover time and 'age' of water in the dolomite aquifers and from it the ratio of the aquifer storage to the average annual recharge, which would provide an estimate of the storage water in relation to the annual recharge

- Indicated a linear relationship between the bicarbonate concentrations of the springs and the recharge coefficients as derived from the chloride mass balance method, assuming the latter to be reliable.

Furthermore:

- The model could be used to assess the reliability of tritium and CFC as tracers and to interpret differences in their results in terms of the conceptual model

- It could be shown that an exponential regression relationship exist between the rainfall and recharge that has been obtained from the ${ }^{14} \mathrm{C}$ model to be used as a general equation to obtain the variability of monthly recharge from rainfall

- It has demonstrated the significance of ${ }^{14} \mathrm{C}$, tritium and CFC to provide a better understanding of the flow of water in dolomitic aquifers, more effective utilisation and better assessment of pollution in these valuable groundwater resources.

\section{Acknowledgements}

Acknowledgements are due to JC Vogel for his critical review of the method during many fruitful discussions that have made a significant input to the model, and to the Water Research Commission for the funding of the project.

\section{References}

BEEKMAN HE and XU Y (2003) Groundwater Recharge Estimation in Southern Africa. UNESCO IHP publication, Paris.

BREDENKAMP DB (2000) Groundwater Monitoring: A Critical Evaluation of Groundwater Monitoring in Groundwater Resources Evaluation and Management. WRC Report No. 838/1/00. Water Research Commission, Pretoria, South Africa.

BREDENKAMP DB and VOGEL JC (1970) Study of a dolomitic aquifer with carbon-14 and tritium. In: Isotope Hydrology, 1970. International Atomic Energy Agency, Vienna. 349-372.

BREDENKAMP DB, WIEGMANS FE and FOSTER MBJ (1985) Dolomitic aquifer southeast of Pretoria as an emergency groundwater supply. Proc. Symp. Hydrogeology of Rocks of Low Permeability. Tucson, Arizona, USA.

BREDENKAMP DB, JANSE VAN RENSBURG H, VAN TONDER GJ and BOTHA LJ (1995) Quantitative Estimation of Groundwater Recharge and Aquifer Storativity. WRC Report No TT 73/95. Water Research Commission, Pretoria South Africa.

BREDENKAMP DB and VAN WYK E (2005) Simulation of thermonuclear ${ }^{14} \mathrm{C}$ in springs and its hydrological interpretation. In: Proc. Biennial Groundwater Conference. CSIR Conference Centre, Pretoria, South Africa. March 2005.

ENSLIN JF and KRIEL JP (1967) The assessment and possible future use of the dolomitic groundwater compartments of the Far West Rand, Transvaal, Republic of South Africa. Proc. Int. Conf. Water for Peace. Vol. 2. Washington, USA. May 1967.

FLEISHER JNE (1981) The Geohydrology of the Dolomitic Aquifers of the Malmani Subgroup in the South-Western Transvaal, Republic of South Africa. Report Gh 3169, Department of Water Affairs, Pretoria.

FOSTER MBJ (1988) Geological Control of the Aquifer Properties of the Chuniespoort Group in the Klip River Valley and Natalspruit Basin, Transvaal. Unpublished M.Sc. Thesis, Dept of Geography, Rhodes University, Grahamstown.

MALOSZEWSKI P and ZUBER A (1996) Lumped parameter models for interpretation of environmental tracer data. Manual on Mathematical Models in Isotope Hydrogeology. IAEA 9-58.

SIMONIC M (1993) Interpretation of Aquifer Pollution in the Zuurbekom South-Eastern Sub Compartment. Technical Report GH 3800, Directorate Geohydrology, Department of Water Affairs and Forestry, RSA.

STEPHENS A, NEWTON L, MISCHKER CA, BREDENKAMP DB and REID KO (2005) Situation Analysis for the Preparation of Institutional Arrangements of Groundwater Management. Part 3: Geohydrological Assessment. WRC Report No 1324/1/05. Water Research Commission, Pretoria, South Africa.

TALMA AS and WEAVER JMC (2003) Evaluation of Groundwater Flow Patterns in Fractured Rock Aquifers using CFCs and Isotopes. WRC Report No. 1009/1/03. Water Research Commission, Pretoria, South Africa.

TAYLOR CJ (1983) A Geohydrological Investigation in the Lichtenburg Area, Bo Molopo Subterranean Water Control Area. Technical Report GH 3277, Department of Water Affairs and Forestry. Pretoria.

VEGTER JR and FOSTER MBJ (1990) The Hydrogeology of Dolomitic Formations in the Southern and Western Transvaal. Internal Report, Department of Water Affairs.

VELTMAN S (2003) A Methodology for Groundwater Management in Dolomitic Terrains with the Schoonspruit Compartment as Pilot Area. Unpublished M.Sc. Thesis, Department of Geohydrology, University of the Free State, South Africa.

VOGEL JC (1970) Carbon-14 dating of groundwater. In: Isotope Hydrology 1970. International Atomic Energy Agency, Vienna. 225-239. 